\title{
Microfinance and Shelter: An Impact Assessment of Microfinance on Improving Housing Conditions of Rural Sri Lanka
}

\author{
A. J. M. Chandradasa \\ University of Ruhuna, Matara, Sri Lanka
}

\begin{abstract}
This paper examines the impact of microfinance (MF) programmes on improving the shelter conditions of beneficiary households of Southern Province in Sri Lanka. The ownership of conditional house is one of key indicators measure fulfilling the basic needs of a household on the one hand and healthiness of it on the other. The study is based on the data and information gathered from a sample survey of 405 microfinance recipients of four national level leading Microfinance Institutions (MFIs) in Sri Lanka for 2017. These include: Thrift and Credit Cooperative Societies (TCCSs), Samurdhi Banking Societies (SBSs), Ruhuna Development Bank (RDB), and Sarvodaya Economic Enterprise Development Societies (SEEDS). For analysis purpose, a comparison group has been selected from the existing MF recipients whose membership duration with microfinance (MF) is not longer than one year to compare their shelter status with that of existing MF recipients whose membership duration with MF programmes is longer than one year. Three indicators: size of living space, conditions of the house, and current market value of a dwelling house are used for assessing the impact. Based on the data analysis, the study found that Microfinance has benefited the Borrowing Households (BHHs) to improve their shelter status in terms of all the indicators of housing conditions (except roof condition), size of living space, and market value of a dwelling house.
\end{abstract}

Keywords: microfinance, impact, shelter, Sri Lanka

\section{Introduction}

Microfinance (MF) is the most important innovation in the field of "Financial Development and Economic Growth" during the last century. It has been widely accepted as an effective instrument of sustained economic growth through rural development and poverty reduction by promoting investment in small enterprises both rural as well as urban areas. More recently, the development economists laid emphasis on microfinance as an economic development approach intended to benefit low-income people and better way to achieve Millennium Development Goals (MDGs) including reducing poverty, supporting gender equity, encouraging more equitable income distribution, developing the private sector, and promoting participatory development (Littlefield, Morduch, \& Hashemi (2003).

In MF theory, it is often argued that small lending to the poor is not only benefits on the income

A. J. M. Chandradasa, Senior Lecturer, Department of Economics, University of Ruhuna, Matara, Sri Lanka.

Correspondence concerning this article should be addressed to A. J. M. Chandradasa, Department of Economics, University of Ruhuna, Matara, 81000, Sri Lanka. 
generating economic activities but also on basic needs including development of shelter conditions of Borrowing Households (BHHs), whether in terms of constructing new houses or developing the part of existing houses by the Borrowing Households. However, microfinance practitioners are lukewarm in financing the housing loans directly as their little economic of scale. But it does not mean that the MF has not evolved with improving the living conditions including shelter conditions of BHHs. However, in the empirical literature, the researchers in their impact assessment studies on MF have mostly focused only to direct impacts such as enterprise development (Kumar, 2017); income effect (Hulme, \& Mosley, 1996); women empowerment (Devi, 2014; Herath, Guneratne \& Sanderatne, 2015) and improved standard of living (Imoisi, Anthony Ilegbinosa, \&etal, 2014) of the recipients. By contrast to these positive impact of MF, a contentious discussion has emerged in recent years on the MF is known as "microfinance crisis". According to the official talks in different forum in the country, microfinance sector in conflict affected areas (North and Eastern provinces) in Sri Lanka is also exhibiting some features of microfinance crisis situation. In addition to that Sri Lankan society is annually facing the disaster such as flood. With these unanticipated incidences, there may emerge huge demand for MF for non-productive purposes such as rehabilitating residential houses, illness, crop failure and consumption smoothing so on. Meanwhile, MF sector in Southern Province in Sri Lanka had continued relatively normal situation even over the period of ethnic conflict situation which continued over three decade since 1980s. With this background, household level analysis of the impact of MF on dwelling houses conditions in the areas with the normal situation may be more important in policy making point of view for the microfinance sector in a post conflict society. The objective of the study is therefore to analyze the impact of microfinance in improving the shelter conditions of Borrowing Households (BHHs) of Southern Province in Sri Lanka.

This paper is divided into six sections. The first section is the introduction. The second section describes the survey design and analytical methods of this study. In the sections: third, fourth, and fifth, will discuss the impacts of micro-finance on three aspects of shelter conditions. Finally, the conclusion of the paper is presented.

\section{Methodology}

The qualitative and quantitative data were collected from a sample survey of 405 microfinance recipients of the four national level leading MF Institutions (MFIs) operating in the MF market of Southern Province. These include Thrift and Credit Cooperative Societies (TCCSs) from the structures of cooperative financials, Samurdhi Banking Societies (SBSs) from the government sector, Ruhuna Development Bank (RDB) from the semi-government structured MFIs, and Sarvodaya Economic Enterprise Development Societies (SEEDS) from Non-government Institutions. Multi-stage sampling technique has been applied in selecting the respondent households. In the first stage all districts: Galle, Matara, and Hambantota in the Province have been selected to cover the geographical context in the region. In the second stage, four leading MFIs working in the market have been selected to cover the different types of MF practitioners act in the field. In final step, 10 villagers have been selected in order to reach the final beneficiary of MF. For analysis purpose, a comparison group has been selected from the existing members whose membership with MF is no longer than one year to compare their

\footnotetext{
1 The term means to over-indebtedness emerging among microfinance customers. Under the competitive pressure to repay the borrowings from nultiple MFIs, borrowers have shown a growing inclination to repay their micro credit by taking out another loan with a defferent MFIs or from a money lenders and will result the overinddtness.
} 
shelter status with that of existing members whose membership with MF programmes is longer than one year. Herein former group of households are labelled as Comparison Households (CHHs) while the latter group of households are as BHHs. Size of the sample is 405, comprising with 97 beneficiaries in CHHs and 308 beneficiaries in BHHs. The group, BHHs again divided into two sub sample as Borrowing Households Group 2 $\left(\mathrm{BHHsG}_{2}\right)$ and Borrowing Households Group $3\left(\mathrm{BHHsG}_{3}\right) . \mathrm{BHHsG}_{2}$ refers to the $\mathrm{MF}$ recipients whose membership with MF programmes is longer than one year but less than four years. $\mathrm{BHHsG}_{3}$ refers to the MF recipients whose membership with MF programmes is longer than four years. Three indicators: living space, shelter condition, and current market value of a dwelling house are used for assessing the impact. The study period is 2017. The theoretical foundation selecting these indicators can possibly to explain in following ground.

Impact of credit on shelter conditions of Borrowing Households is possible through two channels: directly or indirectly. First channel is directly through housing loans and second would be indirectly through its spill over effect of credit to the enterprise sector of the households. This theoretical argument can easily be explained with help of Figure 1.

As seen in Figure 1, the enforcement of MF for dwelling houses and development encounters through two group of factors namely, capabilities factors and encouraging factors. Right-hand side of the figure indicates the capabilities factors while the left-hand side indicates the encouraging factors. With this theoretical explanation, housing development is the single encouraging factor attributing the development. Housing development would be from different aspects. These can be divided into two as increasing the living space and promoting the condition of existing houses. Cumulative outcome of these changes is the increasing of the market value of dwelling house of BHHs. As seen in Figure 1, three indicators can be found for assessing the impact of micro-credit on dwelling houses of Borrowing Households. These are the (i) living area in a dwelling house; (ii) housing conditions (roof condition, sidewall condition, and floor condition); and (iii) market value of dwelling houses. Average Treatment Effect is estimated for quantifying the impact effect of MF in improving the conditions in dwelling house of the beneficiary households.

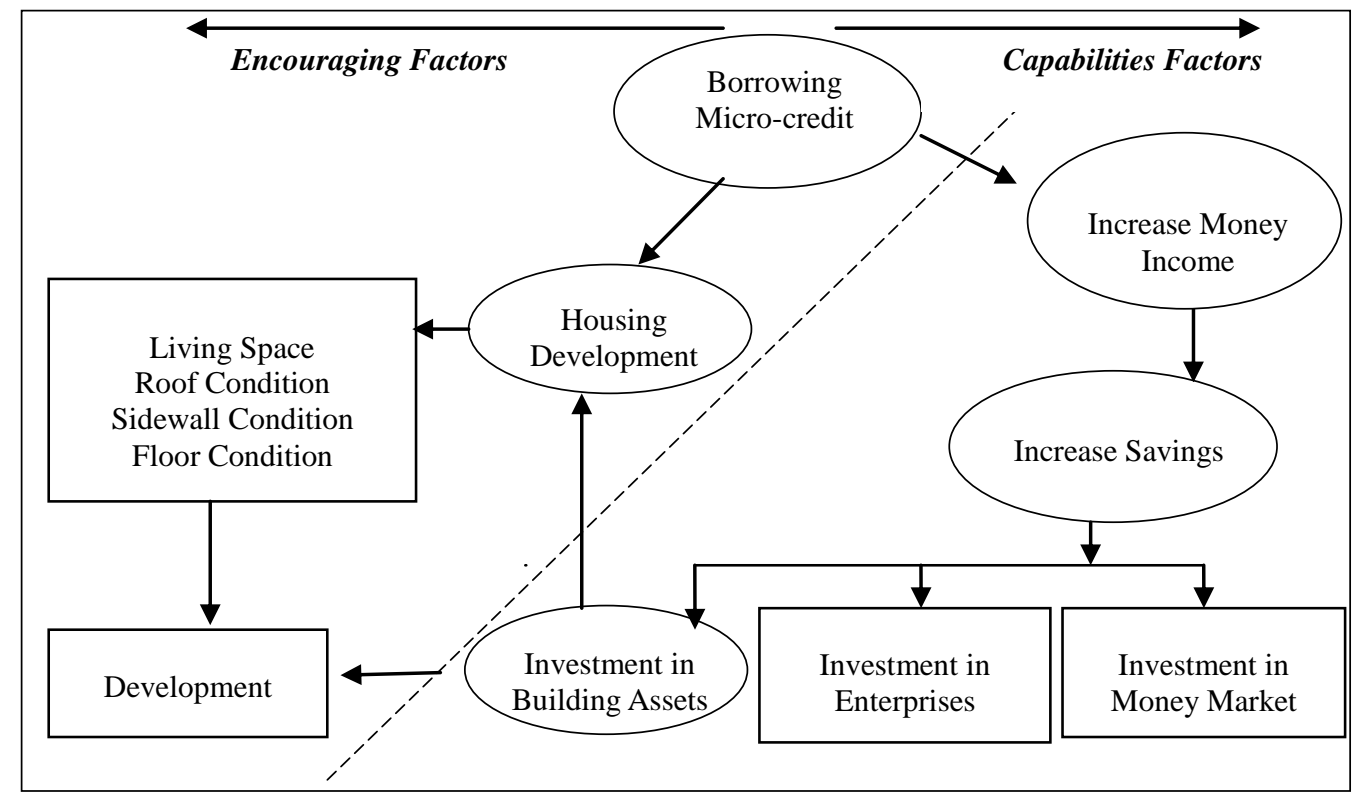

Figure 1. Theory of microfinance, dwelling houses, and development. Source: created by author. 
To confirm the goodness of fitting the sample data in explaining this theoretical argument, correlation coefficients of major three variables namely, total money income, the value of dwelling house, and living space per member of the households has estimated on total credit borrowed by the households. Correlation matrix is presented in Table 1.

Table 1

Correlation Matrix of Microfinance and Dwelling Houses Variables

\begin{tabular}{|c|c|c|c|c|c|}
\hline Variable & Statistics & Total Credit (Rs.) & Total Income (Rs.) & House Value (Rs.) & Living Space (sft.) \\
\hline \multirow{3}{*}{ Total Credit } & Pearson Correlation & 1 & $0.480(* *)$ & $0.224(* *)$ & 0.101 \\
\hline & Sig. (2-tailed) & & 0.000 & 0.000 & 0.077 \\
\hline & $\mathrm{N}$ & 308 & 308 & 305 & 308 \\
\hline \multirow{3}{*}{ Total Income } & Pearson Correlation & & 1 & $0.587(* *)$ & $0.138(*)$ \\
\hline & Sig. (2-tailed) & & & 0.000 & 0.015 \\
\hline & $\mathrm{N}$ & & 308 & 305 & 308 \\
\hline \multirow{3}{*}{ House Value } & Pearson Correlation & & & 1 & $0.339(* *)$ \\
\hline & Sig. (2-tailed) & & & & 0.000 \\
\hline & $\mathrm{N}$ & & & 305 & 305 \\
\hline \multirow{3}{*}{ Living Space } & Pearson Correlation & & & & 1 \\
\hline & Sig. (2-tailed) & & & & \\
\hline & $\mathrm{N}$ & & & & 308 \\
\hline
\end{tabular}

Notes. ** Correlation is significant at the 0.01 level (2-tailed). * Correlation is significant at the 0.05 level (2-tailed). Source: sample survey.

As shown in the correlation matrix in Table 1, the correlation coefficients of variables which included to the test are statistically significant at the 0.01 level, suggesting that the sample data have strong power to explain the theoretical suggestions of MF impact on dwelling houses of BHHs. Next section, BHHs are compared with $\mathrm{CHHs}$ using the performance indicators by different aspects of household wise. To begin, it is important to assess the impact MF on changing the living space in dwelling houses of BHHs.

\section{Impact of MF on Changing the Average Living Space of Dwelling Houses of BHHs}

Overall, Table 2 shows a positive impact of MF in improving the shelter conditions of Borrowing Households when compared with the Comparison Households in terms of average living space.

Table 2

Impact of MF on Shelter (Increase Living Space)

\begin{tabular}{|c|c|c|c|c|}
\hline \multirow[b]{2}{*}{ Category } & \multirow[b]{2}{*}{ Count } & \multirow{2}{*}{$\begin{array}{l}\text { Control Group } \\
\text { (CHHs) }\end{array}$} & \multicolumn{2}{|c|}{ Longer of Membership } \\
\hline & & & $\begin{array}{l}1-4 \text { Years } \\
\left(\mathrm{BHHsG}_{2}\right)\end{array}$ & $\begin{array}{l}\text { 4< Years } \\
\left(\mathrm{BHHsG}_{3}\right)\end{array}$ \\
\hline \multicolumn{5}{|c|}{ (A) Mean Comparison } \\
\hline Mean sqf. & & 609.46 & 671.40 & 733.91 \\
\hline Mean Difference & & & 61.939 & 124.449 \\
\hline T-Value & & & 1.489 & 2.770 \\
\hline Sig. $\mathrm{t}$ & & & 0.138 & 0.006 \\
\hline \multicolumn{5}{|c|}{ (B) Absolute Value of a House (No. of Houses as \% of Total) } \\
\hline \multirow{2}{*}{ Less than 500 sqf. } & Count & 39 & 62 & 32 \\
\hline & $\%$ within Group & $40.2 \%$ & $33.3 \%$ & $27.8 \%$ \\
\hline
\end{tabular}


Table 2 to be continued

\begin{tabular}{lllll}
\hline 500-1,000 sqf. & Count & 47 & 91 & 61 \\
& $\%$ within Group & $48.5 \%$ & $48.9 \%$ & $53.0 \%$ \\
Greater than 1,000 sqf. & Count & 11 & 33 & 22 \\
& $\%$ within Group & $11.3 \%$ & $17.7 \%$ & $19.1 \%$ \\
Total & Count & 97 & 186 & 115 \\
(C) Chi-Square Tests & $\%$ within Group & $100.0 \%$ & $100.0 \%$ & $100.0 \%$ \\
Pearson Chi-Square & & & 2.527 (a) & 4.677 (b) \\
& Value & & 0.283 & 0.096 \\
Likelihood Ratio & Sig. (2-sided) & & 2.602 & 4.719 \\
& Value & & 0.272 & 0.094 \\
\hline
\end{tabular}

Notes. a. 0 cells $(0.0 \%)$ have expected count less than 5. The minimum expected count is 15.08 . b. 0 cells $(0.0 \%)$ have expected count less than 5 . The minimum expected count is 15.10 . Source: sample survey.

Panel (A) in Table 2 indicates that the average (mean) living space in dwelling houses of $\mathrm{BHHsG}_{2}$ is 671.40 sqf. Average living space in dwelling houses of Comparison Households (CHHs or $\mathrm{BHHsG}_{1}$ ) is 609.46 (sqf.). Calculated t-value on mean difference (61.9) is 1.489; however, this t-value is not statistically significant at $10 \%$ level (0.13). This means that MF has not considerably benefited on dwelling houses of $\mathrm{BHHsG}_{2}$ with compared the CHHs in term of living space in dwelling houses of BHHs. In contrast, the average living space in dwelling houses of the $\mathrm{BHHsG}_{3}$ reflects the positive benefits of $\mathrm{MF}$ of $\mathrm{BHHsG}_{3}$ in terms of living space in the dwelling houses compared with the CHHs. For example, mean deference of living space in a dwelling house between CHHs and BHHs3 is $124.45 \mathrm{sft}$. Calculated t-value of this mean deference is 2.770 and significant value of this $\mathrm{t}$-value is 0.006 , indicating that the calculated $\mathrm{t}$-value on mean differences of living space is significantly greater than the critical $\mathrm{t}$-value of 0.05 . Likewise, average living space of a dwelling house of $\mathrm{BHHsG}_{3}$ is greater (9.3\%) compared with that of average living space of a dwelling house of $\mathrm{BHHsG}_{2}$. This finding does suggest that a significant correlation is between the benefits of MF and the longer of membership with the MF programmes.

Cross tabulation statistics in Panel (B) in the Table 2 further reveals that within $\mathrm{BHHsG}_{3}, 72.1 \%$ of total household are living in a house that has living space more than 500 square feet. Meanwhile, within $\mathrm{BHHsG}_{2}$, $66.6 \%$ of households are living in a house with a living space more than 500 square feet. In contrast, within CHHs, percentage of a dwelling house larger than 500 square feet is regularly diminishing to the 59.8\%. Pearson Chi Square Test shows that absolute difference of average living space available to the households in $\mathrm{BHHsG}_{2}$ is not statistically significant (0.28) at the level of $5 \%$, but t-value of $\mathrm{BHHsG}_{3}$ is slightly significant at critical value of 0.10. On the basis of this (t-test and Chi-Square Tests), it can be suggested that $\mathrm{BHHsG}_{3}$ have higher impact of MF in term of living space in dwelling house. In general however, most households in both cases of groups are living in a house with small living spaces more often around 500-1,000 square feet.

\section{Impact of MF on Developing the Housing Conditions of BHHs}

In this section, the housing conditions of BHHs are compared with the housing conditions of CHHs using three indicators: the roof condition, sidewall condition, and floor condition.

Roof condition. Table 3 shows the condition of roof of dwelling houses of respondents in the whole sample by means of material used for roofing. We believed that tiles or asbestos are the better and permanent 
roofing products used in case of Sri Lanka.

Table 3

Impact of MF on Shelter (Roof Condition)

\begin{tabular}{|c|c|c|c|c|}
\hline \multirow[b]{2}{*}{ Category } & \multirow[b]{2}{*}{ Count } & \multirow[b]{2}{*}{$\begin{array}{l}\text { Control Group } \\
\text { (CHHs) }\end{array}$} & \multicolumn{2}{|c|}{ Longer of Membership } \\
\hline & & & $\begin{array}{l}1-4 \text { Years } \\
\left(\mathrm{BHHsG}_{2}\right)\end{array}$ & $\begin{array}{l}4<\text { Years } \\
\left(\mathrm{BHHsG}_{3}\right)\end{array}$ \\
\hline (A) & Count & 1 & 0 & 0 \\
\hline Leaves & $\%$ within Group & $1.0 \%$ & $0.0 \%$ & $0.0 \%$ \\
\hline \multirow{2}{*}{ Tin } & Count & 7 & 5 & 8 \\
\hline & $\%$ within Group & $7.2 \%$ & $2.7 \%$ & $7.0 \%$ \\
\hline \multirow{2}{*}{ Tiles } & Count & 69 & 147 & 92 \\
\hline & $\%$ within Group & $71.1 \%$ & $79.0 \%$ & $80.0 \%$ \\
\hline \multirow{2}{*}{ Asbestos } & Count & 18 & 32 & 13 \\
\hline & $\%$ within Group & $18.6 \%$ & $17.2 \%$ & $11.3 \%$ \\
\hline \multirow{2}{*}{ Other } & Count & 2 & 2 & 2 \\
\hline & $\%$ within Group & $2.1 \%$ & $1.1 \%$ & $1.8 \%$ \\
\hline \multirow{2}{*}{ Total } & Count & 97 & 186 & 115 \\
\hline & $\%$ within Group & $100.0 \%$ & $100.0 \%$ & $100.0 \%$ \\
\hline \multicolumn{5}{|l|}{ (B) } \\
\hline \multicolumn{5}{|l|}{ Chi-Square Tests } \\
\hline \multirow[t]{2}{*}{ Pearson Chi-Square } & Value & & 6.027 (a) & $5.000(b)$ \\
\hline & Sig. (2-sided) & & 0.197 & 0.416 \\
\hline \multirow[t]{2}{*}{ Likelihood Ratio } & Value & & 6.037 & 5.756 \\
\hline & Sig. (2-sided) & & 0.196 & 0.331 \\
\hline
\end{tabular}

Notes. a. 5 cells $(50.0 \%)$ have expected count less than 5 . The minimum expected count is 0.34 . b. 6 cells $(50.0 \%)$ have expected count less than 5 . The minimum expected count is 0.46 . Source: sample survey data.

Table 3 reveals that on average, around $92.4 \%$ of households have houses with a permanent roof whether with roofing product of tiles or asbestos. Table further shows that as a percentage within group, $80.0 \%$ of $\mathrm{BHHsG}_{3}$ and $79.0 \%$ of $\mathrm{BHHsG}_{2}$ have a roof of tiles. The percentage of the dwelling houses with a permanent roof in case of CHHs however, has slightly declined to $71.1 \%$. Overall Table 3 shows that the roof condition of dwelling houses in all cases of households are in the same condition, reflecting the neutrality of the impact of MF shelter in terms of roof condition.

$18.6 \%$ of $\mathrm{CHHs}, 17.2 \%$ of $\mathrm{BHHsG}_{2}$, and $11.3 \%$ of $\mathrm{BHHsG}_{3}$ have houses with a roof condition of asbestos. Further $7.2 \%$ of $\mathrm{CHHs}, 2.7 \%$ of $\mathrm{BHHsG}_{2}$, and $7.0 \%$ of $\mathrm{BHHsG}_{3}$ have a roof of tin. Likewise, $2 \%$ for all the groups have a roof of partially tin and partially local tiles (other). Most importantly one house (1.0\%) was only found in the sample with a roof of leaves.

Estimated Pearson Chi-Square test on differences of the roof condition in dwelling houses of BHHs is not statistically significant at expected level (0.05). On the base of this result, it can be suggested that MF impact of shelter of BHHs of Southern Province in Sri Lanka is neutral with compared the CHHs in term of roofing condition.

Sidewall condition. Data collected from the MF beneficiary sample survey for this study reveals that the walls of dwelling houses of both cases of BHHs and CHHs have permanently built by using durable materials 
whether such kind is of baked brick, cement brick, clay-brick or granite. Table 4 shows the condition of sidewall of dwelling houses by household wise. We believe in this study that the housing condition with cement plastered sidewalls is the highest condition. It is very clear from the Table 4 that more than $46 \%$ of dwelling houses of $\mathrm{CHHs}$ are with the condition of non-plastering side walls. Meanwhile, the number of houses with the condition of non-plastering walls are regularly diminishing to $19.9 \%$ in the category of $\mathrm{BHHsG}_{2}$ and further, to $7.0 \%$ for $\mathrm{BHHsG}_{3}$.

In contrast, as seen in Table 4, the BHHs have a dwelling house with higher quality or finishing sidewall in terms of plastering than that of $\mathrm{CHHs}$.

For examples, $85.1 \%$ of $\mathrm{BHHsG}_{3}$ have a dwelling house with the sidewall condition of cement plastering. But the percentage share of houses with cements plastered sidewalls has decreased to $71.5 \%$ for $\mathrm{BHHsG}_{2}$ and it steadily decreased further to $42.3 \%$ for CHHs. With these observations it can be suggested that BHHs have higher quality of physical life compared with the CHHs in terms of housing condition with finishing quality of the sidewalls. Calculated values of both the Pearson Chi-Square test and Likelihood Ratio on this hypothesis are strongly significant at the level of three zero decimals in statistical sense. It means that that impact of MF on shelter is remarkably higher in BHHs compared with the CHHs in term of housing condition of sidewalls.

Table 4

Impact of MF on Shelter (Sidewall Condition)

\begin{tabular}{|c|c|c|c|c|c|}
\hline \multirow{2}{*}{ Category } & \multirow{2}{*}{ Count } & \multirow{2}{*}{$\begin{array}{l}\text { Control } \\
\text { Group }\end{array}$} & \multicolumn{2}{|c|}{ Longer of Membership } & \multirow[t]{2}{*}{ Total } \\
\hline & & & 1-4 Years & $4<$ Years & \\
\hline \multirow{2}{*}{$\begin{array}{l}\text { (A) } \\
\text { Non Plastering }\end{array}$} & Count & 45 & 37 & 8 & \\
\hline & $\%$ within Group & $46.4 \%$ & $19.9 \%$ & $7.0 \%$ & \\
\hline \multirow{2}{*}{ Mud } & Count & 10 & 15 & 9 & \\
\hline & $\%$ within Group & $10.3 \%$ & $8.1 \%$ & $7.9 \%$ & \\
\hline \multirow{2}{*}{ Cement } & Count & 41 & 133 & 97 & \\
\hline & $\%$ within Group & $42.3 \%$ & $71.5 \%$ & $85.1 \%$ & \\
\hline \multirow{2}{*}{ Boarded } & Count & 1 & 1 & 0 & \\
\hline & $\%$ within Group & $1.0 \%$ & $0.5 \%$ & $0.0 \%$ & \\
\hline \multirow{2}{*}{ Total } & Count & 97 & 186 & 114 & \\
\hline & $\%$ within Group & $100.0 \%$ & $100.0 \%$ & $100.0 \%$ & \\
\hline \multicolumn{6}{|l|}{ (B) Chi-Square Tests } \\
\hline \multirow[t]{2}{*}{ Pearson Chi-Square } & Value & & 24.897 (a) & 48.553 (b) & \\
\hline & Sig. (2-sided) & & 0.000 & 0.000 & \\
\hline \multirow[t]{2}{*}{ Likelihood Ratio } & Value & & 24.528 & 51.955 & \\
\hline & Sig. (2-sided) & & 0.000 & 0.000 & \\
\hline
\end{tabular}

Notes. Source: sample survey.

Floor condition. General, we believe that floor of the dwelling houses with cement or floor tiled is the better condition of a house in case of Sri Lanka. Table 5 shows the condition of floor of dwelling houses by household wise.

As an alternative indicator to measure the condition of dwelling houses, floor condition also shows a positive result in favour of BHHs compared with the CHHs. For example, Table 5 reveals that $74.8 \%$ of $\mathrm{BHHsG}_{3}$ and $60.8 \%$ of $\mathrm{BHHsG}_{2}$ have houses with floor of cement in their dwelling houses. In contrast, there 
are $39.2 \%$ households of $\mathrm{CHHs}$ are only having a house with the floor condition of cement. Furthermore, while only $9 \%$ of $\mathrm{BHHsG}_{3}$ and $15.1 \%$ of $\mathrm{BHHsG}_{2}$ have floor of cow-dung, the percentage share increases to $30.9 \%$ for CHHs. The percentage of dwelling houses with concrete floor is regularly diminishing as $24.7 \%$ for $\mathrm{CHHs}$, $19.9 \%$ for $\mathrm{BHHsG}_{2}$, and $15.7 \%$ for $\mathrm{BHHsG}_{3}$.

To polarize the impact of MF on housing condition of BHHs relative to that of CHHs in term of floor condition, we calculate the Chi-Square Value on average difference of housing condition between two groups of households: CHHs and BHHs. The results present in Panel (B) of Table 5. As it is seen in the table, Chi-Square Tests results on the housing conditions of $\mathrm{BHHsG}_{2}$ in term of floor are statistically significant at level of 0.05 compared with that of CHHs. Meanwhile, floor condition of a dwelling house in $\mathrm{BHHsG}_{3}$ is strongly significant at the level of three zero decimals (0.000) in statistical sense compared with the CHHs. On the base of this result, it can be suggested that BHHs have significantly higher condition of houses in terms of the house conditions of floor compared with that of the CHHs.

Table 5

Impact of MF on Shelter (Floor Condition)

\begin{tabular}{|c|c|c|c|c|}
\hline \multirow[b]{2}{*}{ Category } & \multirow[b]{2}{*}{ Count } & \multirow{2}{*}{$\begin{array}{l}\text { Control Group } \\
\text { (CHHs) }\end{array}$} & \multicolumn{2}{|c|}{ Duration of Membership } \\
\hline & & & $\begin{array}{l}\text { 1-4 Years } \\
\left(\mathrm{BHHsG}_{2}\right)\end{array}$ & $\begin{array}{l}<<\text { Years } \\
\left(\mathrm{BHHsG}_{3}\right)\end{array}$ \\
\hline \multirow{2}{*}{$\begin{array}{l}\text { (A) } \\
\text { Cow-dung }\end{array}$} & Count & 30 & 28 & 1 \\
\hline & $\%$ within Group & $30.9 \%$ & $15.1 \%$ & $0.9 \%$ \\
\hline \multirow{2}{*}{ Cement } & Count & 38 & 113 & 86 \\
\hline & $\%$ within Group & $39.2 \%$ & $60.8 \%$ & $74.8 \%$ \\
\hline \multirow{2}{*}{ Concrete } & Count & 24 & 37 & 18 \\
\hline & $\%$ within Group & $24.7 \%$ & $19.9 \%$ & $15.7 \%$ \\
\hline \multirow{2}{*}{ Floor Tile } & Count & 5 & 8 & 9 \\
\hline & $\%$ within Group & $5.2 \%$ & $4.3 \%$ & $7.8 \%$ \\
\hline \multirow{2}{*}{ Other } & Count & 0 & 0 & 1 \\
\hline & $\%$ within Group & $0 \%$ & $0 \%$ & $0.9 \%$ \\
\hline \multirow{2}{*}{ Total } & Count & 97 & 186 & 115 \\
\hline & $\%$ within Group & $100.0 \%$ & $100.0 \%$ & $100.0 \%$ \\
\hline \multicolumn{5}{|l|}{ (B) Chi-Square Tests } \\
\hline \multirow[t]{2}{*}{ Pearson Chi-Square } & Value & & 14.198 (a) & $47.524(b)$ \\
\hline & Sig. (2-sided) & & 0.003 & 0.000 \\
\hline \multirow[t]{2}{*}{ Likelihood Ratio } & Value & & 14.048 & 55.090 \\
\hline & Sig. (2-sided) & & 0.003 & 0.000 \\
\hline
\end{tabular}

Notes. a. 1 cells (12.5\%) have expected count less than 5. The minimum expected count is 4.46. b. 2 cells (20.0\%) have expected count less than 5 . The minimum expected count is 46 . Source: sample survey.

\section{Market Value of Dwelling Houses of BHHs}

The current market value of a dwelling house is the next indicator for assessing the impact of MF on shelters of BHHs. In general, the market value of a dwelling house is hardly to be determined by a single factor such as credit, but also a number of factors. Location of the site, social status of the neighbours, and accessibility to social and economic infrastructure facilities and distance to nearest city are some forces determining the monetary value of a house. To filter the actual benefits of credit on shelter, we develop a simple linear model for assessing the causal relationship between credit and market value of a house in BHHs. 
We believe that "distance to the nearest city" is the one and only factor in determining the value of house in addition to the credit which results to improve the different conditions of houses. With this view, the variable, market value of a house is the dependent variable in the model, while the credit and distance to nearest city are the independent variables in it. The relationship of these variables can be written as following functional form:

$$
M V h=\alpha_{0}+\alpha_{1} C r-\alpha_{2} F+e
$$

where

$$
\begin{aligned}
& M V h=\text { Market Value of House } \\
& \alpha_{0}=\text { Constant } \\
& \alpha_{1}=\text { Coefficien } t \\
& C r=\text { Credit } \\
& \alpha_{2} F=\text { far to nearest City } \\
& e=\text { Errer term }
\end{aligned}
$$

\begin{tabular}{|c|c|c|c|c|c|}
\hline Category & $\mathrm{R}^{2}(\mathrm{Ad})$ & F Sig. & $\alpha_{0}$ & $\alpha_{1} C r$ & $\alpha_{2} F s$ \\
\hline $\mathrm{CHHs}$ & 0.32 & 0.006 & 666.787 & $\begin{array}{l}0.181 \\
(0.951)\end{array}$ & $\begin{array}{l}-19.637 \\
(0.003)\end{array}$ \\
\hline $\mathrm{BHHsG}_{2}$ & 0.32 & 0.000 & 638.934 & $\begin{array}{l}2.250 \\
(0.022)\end{array}$ & $\begin{array}{l}-22.072 \\
(0.000)\end{array}$ \\
\hline $\mathrm{BHHsG}_{3}$ & 0.44 & 0.000 & 877.842 & $\begin{array}{l}4.168 \\
(0.004)\end{array}$ & $\begin{array}{l}-44.291 \\
(0.000)\end{array}$ \\
\hline
\end{tabular}

It has been hypothesised that increasing of the credit will result the improving housing conditions and in turn market value of the assets. By contrast, more distance to the city will reduce the value of house. Because there is not an inter-co-linearity problem between independent variables, the model has been regressed on the variable of market value of house and the Table 6 summarizes results.

Table 6

Impact of MF on Market Value of the Dwelling Houses of BHHs

Notes. Source: calculated by using data of survey.

Interpreting the Table 6 , we see that the $F$-test is strongly statistically significant at three zero decimals, which means that the model is significant in statistically sense.

The variable, "distance to nearest city" is in expected sign (negative). It means that market value of a house is regularly diminishing alongside the remoteness of the site form city. The value of $\mathrm{R}^{2}$ square is 0.44 which means that approximately $44 \%$ of the variance of market value of house in $\mathrm{BHHsG}_{3}$ is accounted for the model. The coefficient for credit variable is 4.168 , which means that for one unit increase in credit, it would expect that 4.1 units increase in value of houses if other variables held constant. In contrast, increase of a unit in credit would result only a 2.2 increase in housing value of $\mathrm{BHHsG}_{2}$. On the basis of this analysis it can be suggested that the current market value of a dwelling house in BHHs is higher than that the market value of the dwelling houses of CHHs.

\section{Conclusion}

This study has examined the central importance of microfinance in achieving basic needs of Borrowing 
Households in the aspect of improving shelter status. In analysis, housing condition of a borrowing households whose membership duration with MF is more than one year were compared with the housing condition of Borrowing Households whose membership duration was less than one year using three indicators: size of living space, conditions of the house, and current market value of a dwelling house. The most obvious finding emerging from this study is that MF recipients whose membership is longer than one year have more entitlements on dwelling house conditions (i.e., sidewall condition, floor condition) and larger house (living space) compared to Comparison Households. The current findings add to a growing body of literature on MF that the MF has capabilities to develop the dwelling house of Borrowing Households. The results of the market value of dwelling houses also show that MF beneficiary households with longer membership duration have better living status compared with Comparison Households. On the basis of this analysis it can be concluded that although the microfinance practitioners are lukewarm in financing the housing loans directly due to their little economic of scale, MF has indirectly evolved with better impact on shelter of BHHs compared with the CHHs. Future research should be therefore concentrated towards developing the strategies for provision of housing loan to poor segment of the society. This means that MF should be assist the poorer household to increase their real assets which could be used as collateral of Borrowing Households in accessing the financial facilities of conventional financial institutions.

\section{References}

Devi, S. K. (2014). Microfinance and women empowerment. Global Journal of Multidisciplinary Studies, 3(5).

Ferguson, B. (2018). Housing microfinance: Is the glass half empty or half full? Global Urban Development Magazine, 4(2), $1-19$.

Herath, H. M. W. A., Guneratne, L. H. P., \& Sanderatne, N. (2016). Impact of microfinance on women's empowerment: A case study on two microfinance institutions in Sri Lanka. Sri Lanka Journal of Social Sciences, 38(1), 51-61.

Hulme, D., \& Mosley, P. (1996). Finance against poverty, 1 and 2. Routledge, London.

Imoisi, A. I., \& Opara G. I. (2014). Microfinance and its impact on poverty alleviation: A case study of some microfinance banks in Edo State, Nigeria. American Journal of Humanities and Social Sciences, 2(1), 27.

Kumar, K. N. (2007). Microfinance for entrepreneurial development study of women's group enterprise development in India. In Cumming, D., Dong, Y., Hou, W., \& Sen, B. (eds), Microfinance for entrepreneurial Development, Palgrave Macmillan, Cham.

Littlefield, E., Morduch, J., \& Hashemi, S., (2003). Is microfinance an effective strategy to reach the millennium development goals? CGAP Occasional (Paper No. 24). Washington, DC.

Mosley, P., \& Hulme, D. (1998). Microenterprise finance: Is there a conflict between growth and poverty alleviation? World Development Elsevier, 26(5), 783-790.

Prieto, S. (2017). 2016-2017 state of housing microfinance. Habitat for Humanity. Terwilliger Center for Innovation in Shelter.

Rogaly, \& Rogaly, B. (1996). Microfinance evangelism, "destitute women" and the hard selling of a new anti-poverty formula. Development Practice, 6(2), 100-112.

Vivek K. T., \& Vineet K. T. (2014). The systematic review of literature on research and development of microfinance industry in India international. Journal of Management \& Organizational Studies, 3(3), September. 